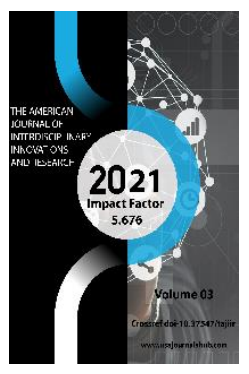

\title{
Prospects For The Improvement Of The Marketing System To Increase The Competitiveness Of Light Industrial Enterprises
}

\author{
Fayoza Tuxtamurodovna Bazarova \\ Senior Lecturer, Tashkent Financial Institute, Uzbekistan
}

Copyright: Original content from this work may be used under the terms of the creative commons attributes 4.0 licence.

\section{ABSTRACT}

The article examines the theoretical and methodological basis of the problems of improving the marketing system to increase the competitiveness of light industry enterprises. A general description of market factors influencing the process of increasing the competitiveness of light industry enterprises is given. In this regard, based on the study of the causes and characteristics of the development of existing problem processes, scientific proposals and practical recommendations for overcoming the existing problems have been formed.

\section{KEYWORDS}

Competitiveness, marketing efficiency, marketing system, marketing strategy, light industry cluster, management system, certification,

\section{INTRODUCTION}

Today, research aimed at improving the competitiveness of light industry enterprises in Uzbekistan on the basis of marketing strategies, including the introduction of innovative marketing systems in enterprises, effective organization of market research, 
development of effective marketing strategies for textile and fashion companies, formation of light industry clusters, e-commerce it is important to establish the system at the international level. Comprehensive measures to increase the effectiveness of reforms in this area are reflected in the Decree of the President of the Republic of Uzbekistan dated December 14, 2017 No PF-5285 "On measures to accelerate the development of the textile and clothing industry." Systemic tasks have been set to ensure the widespread introduction of innovative technologies, including design, know-how, quality management systems and modern marketing services, to promote national brands at exhibitions abroad and to demonstrate the potential of textile enterprises [1].

The above facts show the urgency of conducting research to improve the marketing system to increase the competitiveness of light industry enterprises.

It is expedient to pay special attention to the effectiveness of the market management system in improving the marketing system to increase the competitiveness of light industry enterprises, marketing effectiveness can not be achieved without the formation of effective market activity in the enterprise. Therefore, the development of proposals and recommendations to improve the scientific and methodological framework for enhancing the global reputation of national brands, which leads to a decrease in the effectiveness of marketing activities, is one of the most pressing issues today.

\section{LITERATURE REVIEW}

Research aimed at enhancing the competitiveness of industrial enterprises in the global economy through marketing strategies occupies a special place in Juyoung Lee's research. According to the researcher, the factors shaping the competitive environment in the market of light industrial goods are formed on the basis of the philosophical basis of the relationship in domestic and global markets related to the development of marketing over the past hundred years [2]. ZA Hakimov's research explains the systematization of marketing strategies of light industry enterprises and its specific features. Necessary recommendations on the use of cluster strategy are given to increase the opportunities for effective use of marketing activities in light industry enterprises [3]. A.I. Statsura's research revealed the nature of light industry enterprises and their degree of impact on production, nature, differences from other industries. The factors shaping competition in the market are systematically classified according to the specific characteristics of light industry enterprises [4]. Sh.D.Ergashkhodjaeva, ZAHakimov, ANSamadov studied the international experience in improving the competitiveness of light industry enterprises, widely used marketing strategies and competitive factors and perspectives of enterprises based on the interpretation of the essence of "cluster" theory in marketing activities of enterprises, assortment and competition analysis. The definition of strategies is based on the development of the market in the textile industry and the use of clustering opportunities by assessing the competitive environment in it [5].

A.Sh.Bekmurodov, Be.Yang Son's research studies the general goals and objectives of the formation of clusters on the basis of the marketing system to increase the competitiveness of light industry enterprises, education, science, engineering, It is advisable to combine consulting, standardization, certification and various other services [6].

The above research has studied in detail the process of improving the marketing system to increase the competitiveness of light industry enterprises, but has not studied the processes associated with the role of improving the 
marketing system of light industry enterprises to increase competitiveness.

\section{RESEARCH METHODOLOGY}

The research used the methods of theoretical observation, induction and deduction, systematic analysis, and scientific proposals and practical recommendations for improving the marketing system to increase the competitiveness of light industry enterprises were formed using the method of logical abstraction.

\section{ANALYSIS AND RESULTS}

The process of improving the marketing system to increase the competitiveness of light industry enterprises will depend on the indicators that characterize the competitiveness of the enterprise and the level of use of labor, material and financial resources that determine the competitiveness of enterprises in the market. However, the competitiveness of light industry enterprises is a broader concept, which is directly related to the external activities of other enterprises, as well as performance indicators related to production. These include marketing, management, financial policy, brand policy, branding opportunities, communications, transportation, logistics policy, and more. This, in turn, suggests that internal and external factor strategies have a direct impact on the competitiveness of light industry enterprises.

Improving the competitiveness of light industry enterprises is characterized by a system of training personnel to carry out innovative activities, the introduction of deep technological modernization and innovative development based on advanced technologies in the industry, the creation of new technologies. When analyzing marketing effectiveness, the relative revenue generated by different channels, products, regions, and other marketing objects is seen. The effectiveness of marketing in an enterprise or its division depends on customer focus, marketing integration, data performance, strategic focus and operational efficiency, which depend on the 5 main organizational components of its direction.

All marketing efforts should be used simultaneously in the implementation of marketing activities. No marketing event or move can be allowed to get stuck. This is how marketing activities provide a continuous flow of information from the consumer to industrial enterprises and trade, and from them in the opposite direction. This allows you to make timely changes in production, product range, terms of sale, services. In order to conduct marketing activities, it will be necessary to address organizational issues, including the system of management and planning of the enterprise, distribution, relations in the domestic market and foreign trade, sales through highly equipped market channels. Timely and regular implementation of this work will allow marketing activities to be effective.

One of the important principles of marketing activities is the high quality of goods and services and their competent advertising. High quality of goods and services and their competent advertising is an important condition for the survival of enterprises and organizations in today's fierce competition.

As long as industrial enterprises want to survive in a market economy and continue to operate for a long time, they must be well aware of and follow the laws of competition. In this context, each enterprise must take a new approach to the production process and sales of goods. It is necessary to ensure close coordination of the movement chain of all processes, from the purchase of raw materials to the organization of additional services. 


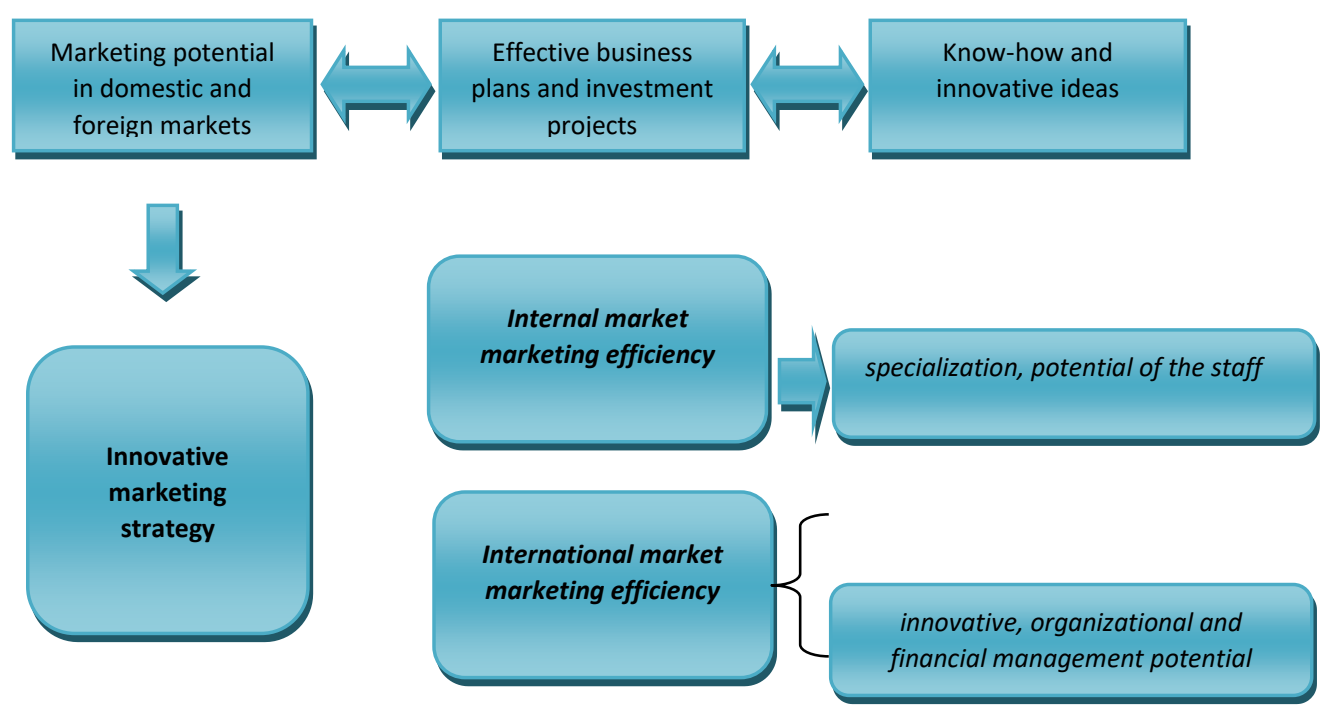

enterprise export potential

Figure 1. Innovative marketing strategy to increase the competitiveness of light industry enterprises.

The marketing system of increasing the competitiveness of light industry enterprises is one of the main directions of a comprehensive study of the market:

- $\quad$ Demand study;

- Determination of the market structure;

- Study of goods;

- Study of competitive conditions;

- Analysis of forms and methods of sales.

Marketing is a set of methods, tools, procedures for enterprises in the market, market methodology, the study of consumers and their needs, the creation of appropriate goods, pricing, supply, delivery, sale of goods, organization of services. Through them, the effective operation of enterprises is carried out.

\section{CONCLUSIONS AND RECOMMENDATIONS}

In the process of improving the marketing system to increase the competitiveness of light industry enterprises, it is necessary to study the market in depth, to correctly define the marketing strategy. In our opinion, improving the marketing system to increase the competitiveness of light industry enterprises requires attention to the tasks of organizing the sales account of the product. These functions include:

- Accurate and timely recording of all business transactions related to the sale of products; 
- Control over the implementation of contracts for the sale of products;

- Control over the range and volume of products sold and the implementation of the sales plan;

- Timely accurate calculation of costs associated with the production and sale of products;

- Accurate calculation of revenue for the product sold, the correct determination of the amount of profit, etc.

In our opinion, when concluding a contract of sale of products in the marketing system of light industry enterprises, the property of the seller of the product can be pledged at the contract value determined in accordance with the agreement of the parties. It is known that when a bank provides loans to enterprises, it pledges their property in the amount of the loan, and if they do not repay the loan, the pledged property is transferred to the bank account. By using this method in the sales process of enterprises, it is possible to reduce the probability of occurrence of receivables and payables between enterprises.

Analyzes show that some Light Industry Enterprises offer their products and do not give the product or return the money for a long time after receiving the money from the buyers. As a result, disputes arise between them and they appeal to the commercial courts. If in the contract the seller pledges the property of the enterprise, the buyer takes the enterprise at his own expense. The contract must state that the seller has no right to sell the mortgaged property until the product is delivered to the buyer. In addition, in order to accelerate the process of selling enterprise products, enterprises must independently organize their pricing policies.

In our opinion, in order to improve the marketing system to increase the competitiveness of light industry enterprises in Uzbekistan, it is necessary to focus efforts and resources in the following areas:
- Ensuring a stable high level of economic growth through the deepening of structural changes in light industry, increasing the innovative factors of economic growth, the transition of the country's economy to a qualitatively new level by halving the material and energy capacity of GDP;

- The priority object of modernization of light industry enterprises should be structures capable of meeting the demand for innovative products, compliance with state educational standards, a favorable investment climate and other elements of sustainable economic growth necessary for the development of innovation infrastructure;

- Improving the competitiveness of domestic goods in foreign markets through the development of new products and high technologies;

- -introduction of energy and water-saving technologies based on the application of new discoveries in industrial production, biotechnology, computer science and nanotechnology and with great potential in many sectors and industries of the national economy;- Diversification of the export structure by deepening the integration of the national economy into the world financial and economic system, increasing the share of competitive finished products in foreign markets to reduce its dependence on foreign economic markets, etc.

\section{REFERENCES}

1. Decree of the President of the Republic of Uzbekistan dated December 14, 2017 No PF-5285 "On measures to accelerate the development of the textile and clothing industry"

2. Juyoung Lee. (2013) Competitiveness of textile and apparel industries in the United States and Japan. Iowa State University. 
Digital Repository @ ISU. Dissertations; Xiajun A, Dorothe'e H. Assortment planning for vertically differentiated products. Production and Operations Management Society. Vol. 21, no. 2, March - April 2012, pp. 253-275

3. Hakimov Z.A. Panel Researching in Study of the Competitive Environment in Clothing Market. // Journal of Accounting Marketing. 2017. Volume 6, Issue 3. ISSN: 2168-9601. DOI: 10.4172 / 21689601.1000251. Impact Factor (JIF) 0.13.

4. Statsura A.I. Formation and development of competitiveness of predprinimatelskoy structure on the market of textile products. Dis. on sois. three. step. k.e.n. SPb. 2009

5. Ergashkhodjaeva Shakhnoza Djasurovna, Hakimov Ziyodullo Ahmadovich, Samadov Askarjon Nishonovich. The Ways of Improving Competitiveness Of Textile Industry Enterprises Based On Marketing Strategies. European Journal of Molecular \& Clinical Medicine 762ISSN 2515-8260 Volume 07, Issue 07, 2020., 751-762 pg.

6. Bekmurodov A.Sh, Yang Son Be. Strategy for the development of textile industry in Uzbekistan: Cluster approach. Monograph. - Tashkent: TGEU, 2006. - 112 p.

7. Toshpulatov I.A. Improving the cluster model in ensuring the competitiveness of light industry enterprises. ECONOMY AND FINANCE / ECONOMY I FINANCE 2019, 3 (123), pp. 11-17 